\title{
BARLEY AND BREWING
}

$\mathrm{T}$ HE European Brewery Convention belongs wholly to the post-war period and, in retrospect, it is surprising that, prior to its inception, no organization existed for the regular international exchange of scientific information and experience in relation to malting and brewing. There were of course various journals of high repute, but the differences in standards, industrial mothods and laboratory procedures from country to country wer $\ni$ not widely approciated. Consequently, valuable though many published investigations were, they tended more to deseribe particular experience than verifiable fact. With the present volume in mind*, it can be still more clearly seen that the selection of barleys and of malting methods even in a single country could scarcely have been done scientifically so long as the lack of properly documented experience made it impossible to coordinate the economic and material requirements of the farmer, maltster and brewer.

The tenth annual report reveals that these earlier deficiencies have been largely remedied by a degree of integration in international investigation never before achieved in this connexion. For example, it gives, mostly in tabular form, the results of trial comparative cultivations, often with relevant malting and brewing trials, of some 12 new varieties of barley the majority of which were grown under highly controlled conditions in $\mathbf{1 4}$ western European

* European Brewery Convention. Rep. Barley Committee, 1959. Pp. 170. (London: Institute of Brewing, 1960.) countries. The data exterid far beyond the expected facts on such matters as yield, nitrogen-content, dormancy, grind characteristics of the malts and head retention of the final beers making up the series of part-reports, each under separate authorship. Thus they include numerous details of the lay-out of each trial, the nature of its location, agricultural conditions, field observations and meteorological data. The report is therefore a reference work rather than a book to be read cursorily. Thero can be no doubt that it reflects what is, in its way, an exceptionally important step to find improved varioties of what is the basic raw material of an unusually widespread industry.

It may seem strange to some that this effort is so disseminated when much of the work could apparently be carried out centrally. Actually, however, this type of inquiry is unexpectedly complicated because it involves comparison not only of barleys as such but also of the conditions under which they are grown. and processed. Broadly, therefore, the question arises as to whether the differences between varieties can outweigh the differences arising from varying methods of treatment, for example, of malting method. The European Brewery Convention Barley Committee is in an unrivalled position to sponsor investigations of this kind, and its report has therefore a scientific value beyond that of a factual record of a unique but continuing international exercise.

A. H. Cook

\section{ADMISSION TO UNIVERSITIES IN BRITAIN}

\begin{abstract}
THE third report of an ad hoc Committee on Procedure for Admission of Students to Universities, appointed by the Committee of Vice-Chancellors and Principals of Universities of the United Kingdom in January 1958, has now become available*. The Committee was set up to consider what steps need to be taken to reduce difficulties experienced by candidates for admission and by the schools. The report contains the findings of a working party established under the chairmanship of Dr. A. W. Chapman to report on the methods and techniques by which the multiplication of applications for admission and the consideration of candidates could be reduced, the kind of central organization involved and any changes of principle as regards relations between universities and candidate. The Committee has been forced to conclude that the time has come when universities must consider the establishment of a central organization and a central office in connexion with applications for admission, and it was this conclusion which led to the establishment of the working party. Further, having been satisfied as to the technical feasibility of such central arrangements, the committee also concluded that it must

* Committee of Vice-Chancellors and Principals of the Universities of the United Kingdom. Third Report of an ad hoc Committee on Procedure for Admission of Students. Pp. $v+41$. (London: ComUnited Kingdom, 1961.) 2s. 6 d.
\end{abstract}

now make recommendations which would cause the universities as a matter of urgency to consider the rapid establishment of co-operative arrangements, and this is the whole burden of the report.

The working party quickly recognized that it would be essential to have some kind of central office with information about every candidate and every institution, but equally that a candidate must have liberty to apply to a reasonable number of institutions of his own choice, and that the choosing of their students must remain entirely a matter for the universities.

Three schemes were submitted by the working party for consideration by the ad hoc Committee. One scheme looks to the maintenance of the present system, and the central office would only act as an information centre, as a means of checking candidates stated priorities and acceptances of places, and, in so far as time permitted, as a clearing house. Acceptance of this scheme is not recommended.

The other two schemes provide for a central office, equipped with data-processing machines, to which each candidate would make his or her application, naming a limited, but reasonably generous, number of institutions, to which he or she wishes to apply. It would be the duty of the central office to distribute the applications to the institutions concerned, to act as the channel through which all offers, whether firm or provisional, or rejections are conveyed to the 
candidate, to ensure that no other application remains in force once a candidate has accepted a firm offer, to provide a general clearing-up service operating from the earliest possible date in the admissions season, and to make full information to those who need it. Under the scheme preferred by the ad hoc Committee, though both are recommended to the consideration of the Committee of Vice-Chancellors and Principals, a candidate's applications would be released two or three at a time in an. order chosen and specified by the candidate and a second pair of applications would ordinarily be released only after the results of the first pair had proved unacceptable. It provides that the selector must make a definite decision on an application within a given time-limit and can no longer wait until after his or her General Certificate of.Education results before reaching a decision. Either scheme could be made effective for the intake of October 1964 if immediate steps were taken, and the Committer recommends the convening of a conference of representatives of the universities to consider the two recommended schemes and their application to the needs of the individual institutions.

Neither scheme need adversely affect the direct relation between candidate and institution. In the light of the discussion at the conference, the Committee of Vice-Chancellors and Principals would invite universities to agree to establish a standing advisory council, and to authorize the necessary steps to establish a central office, including a small executive committee which would act as its governing body and control its policy and operation. These proposals and recommendations are limited to universities in England and Wales other than Oxford and Cambridge, but it is hoped that the colleges of Oxford and Cambridge will also consider entering the scheme and that, even if they do not enter fully, they will at least arrange to complete their selections for admission by the end of December or not later than mid-January. The proposals also seem to be applicable without difficulty to the Scottish universities.

Figures appended to the report show that for the institutions covered 151,000 applications were lodged for 1960-61, against 134,000 for $1959-60,121,000$ for $1958-59$ and 70,000 for $1955-56$, and in all 22,650 students were admitted to first degree courses in October 1960, compared with 20,300 in October 1959. Of the applications, 14,000 were from overseas candidates. Except for technological courses, the number of applications increased substantially compared with the previous year, though the number admitted to such courses increased by about 12 per cent. There is a notable decrease in the number of vacant places, except in technology, and there seems to be no doubt that, at present, too few adequately qualified candidates are applying for courses in the technologies and especially in the classical engineering subjects. It would appear that the clearing-up houses, established in the summer of 1960 , as recommended in the ad hoc Committee's second report, have already contributed to the decrease in the number of vacant places.

\title{
CAESIUM-I37 IN AIR, PRECIPITATION, DRINKING-WATER, MILK AND BEEF IN NORWAY DURING 1959 AND 1960
}

\author{
By T. HVINDEN and A. LILLEGRAVEN \\ Division of Physics, Norwegian Defence Research Establishment, Kjeller
}

$\mathrm{C}$ EESIUM-137 in air, precipitation and milk has been regularly measured at Bergen, Røros and Lillestrom. The results for January 1959-December 1960 are shown in Fig. 1 as mean values over periods of two months.

Cæsium-137 in beef-samples from the same districts has also been measured. Cæsium-137 in drinkingwater has been regularly measured at several places.

The Bergen district is a mountainous coastal area, Røros district is a mountainous inland area and Lillestrom district is a lowlend, inland area. The locations are shown on the map in Fig. 1.

As shown in Fig. $1 B$ the concentration of cæsium137 in ground-level air is at nearly the same level at the three measuring sites, and the variations occur simultaneously. There is one maximum during May-June 1959 and another, but much lower, in May-June 1960. The yearly average values are:

$\begin{array}{lccc}\text { District } & 1959 & 1960 & \\ \text { Bergen } & 0.020 & 0.0042 & \mu \mu \mathrm{c} . \text { cæsium-137/m. } \\ \text { Røros } & 0.019 & 0.0045 & , " \\ \text { Lillestrøm } & 0.019 & 0.0044 & , "\end{array}$

The concentration of cæsium-137 per litre precipitation, shown in Fig. $1 C$, also varies in much the same way, but with a somewhat larger difference from site to site. The maximum concentrations in 1959 are found during the periods March-June, and so are the maximum concentrations in 1960 . It appears, nevertheless, from Fig. $1 B$ and $1 C$ that the concentration of cæsium-137 per litre precipitation to a first approximation is proportional to the concentration in ground-level air.

The average crsium-137 concentration in the total yearly precipitation is:

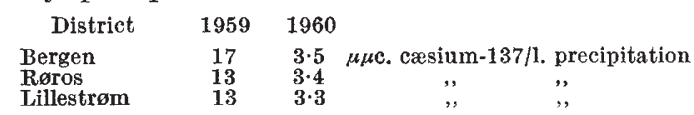

The rate of deposition of cæsium-137 fall-out, shown in Fig. $1 D$, depends on the amount of precipitation, which is very different from site to site. The maximum fall-out rates in 1959 are found during the periods March to August, and so are the maximum rates in 1960 .

The yearly average rate of fall-out is :

$\begin{array}{lccc}\text { District } & 1959 & 1960 \\ \text { Bergen } & 67 & 13 & 13 \\ \text { Roros } & 10 & 4 \cdot 1 & \text { cesium-137/m." per } 24 \mathrm{hr} . \\ \text { Lillestrøm } & 29 & 8 \cdot 9 & ,,\end{array}$

Fig. $1 E$, showing cumulative cæsium-137 fall-out during January 1959-December 1960, reflects the difference in precipitation from site to site. The total yearly fall-out is :

\begin{tabular}{lrrr}
\multicolumn{1}{c}{ District } & 1959 & 1960 & \\
Bergen & $\mathbf{2 4 , 3 0 0}$ & 4,800 & $\mu \mu \mathrm{c}$. cæsium-137/m. \\
Røros & $\mathbf{3 , 8 0 0}$ & 1,500 &,$"$ \\
Lillestrøm & $\mathbf{1 0 , 6 0 0}$ & 3,300 & ",
\end{tabular}

